\title{
Молибдошеелиты медно-молибден-порфировых месторождений и рудопроявлений Карелии (на примере рудных полей Лобаш и Ялонвара)
}

\author{
Кулешевич Л.В., Лавров О.Б. \\ Институт геологии КарНЦ РАН, Петрозаводск, kuleshev@krc.karelia.ru; petrlavrov@list.ru
}

\begin{abstract}
Аннотация. В работе рассмотрен состав шеелитов из медно-молибден-порфировых месторождений и проявлений Карелии, локализованных в архейских зеленокаменных поясах, на примере рудного поля Лобаш и Ялонвара. Шеелиты разных месторождений изучались с использованием электронного сканирующего микроскопа VEGA II LSH (Tescan) с энергодисперсионным микроанализатором INCA Energy-350; руды - с помощью ICP-MS-анализа. Шеелит из молибденовых месторождений часто содержит Мо ${ }^{6+}$, изоморфно замещающий $\mathrm{W}^{6+}$, при этом образуются зональные молибдошеелиты (Лобаш, Ялонвара) и шеелиты, содержащие вростки молибденита (Ялонвара). Шеелит золоторудного месторождения Лобаш-1 не образует значительных скоплений, обычно бывает вкрапленный и по составу однородный. Приводятся новые данные по составу шеелитов и отмечается их различие для медно-молибден-порфировых и золоторудных месторождений, а также обоих месторождений.
\end{abstract}

Ключевые слова: шеелит, молибдошеелит, изоморфизм, месторождения/проявления, Лобаш, Ялонвара, Карелия.

\section{Molybdoscheelites from Karelia's copper-molybdenum-porphyry deposits and ore occurrences (case study of the Lobash and Jalonvaara ore fields)}

\author{
Kuleshevich L.V., Lavrov O.B. \\ Institute of Geology, KarRCRAS, Petrozavodsk, kuleshev@krc.karelia.ru; petrlavrov@list.ru
}

\begin{abstract}
The compositions of scheelites from Karelia's copper-molybdenum-porphyry deposits and occurrences located in Archean greenstone belts, are discussed. The Lobash and Jalonvaara ore fields are used as examples. Scheelites from various deposits were studied using a VEGA II LSH (Tescan) scanning electron microanalyzer with an INCA Energy-350 energy dispersion microanalyzer and the ores using ICP-MS-analysis. Scheelite from molybdenum deposits often contains $\mathrm{Mo}^{6+}$, which replaces $\mathrm{W}^{6+}$ isomorphically; in this case, zonal molybdoscheelites (Lobash, Jalonvaara) and scheelites containing molybdenite ingrowths (Jalonvaara) are formed. Scheelite from the Lobash-I gold deposit does not form large clusters, commonly occurring as disseminated compositionally homogeneous scheelite. New data on the composition of scheelite are presented. Their difference for copper-molybdenum-porphyry and gold deposits, as well as for both deposits, is noted.
\end{abstract}

Keywords: scheelite, molybdoscheelite, isomorphism, deposits/occurrences, Lobash, Jalonvaara, Karelia.

\section{Введение}

Шеелит $\mathrm{Ca}\left[\mathrm{WO}_{4}\right]$ - минерал тетрагональной сингонии. Крайний член изоморфного ряда шеелит $\mathrm{Ca}\left[\mathrm{WO}_{4}\right]$ - повеллит $\mathrm{Ca}\left[\mathrm{MoO}_{4}\right]$. В структуре изолированные тетраэдры $\left[\mathrm{WO}_{4}\right]$ соединены между собой ионами $\mathrm{Ca}^{2+}$. Шеелит из молибденовых месторождений содержит $\mathrm{Mo}^{6+}$, изоморфно замещающий $\mathrm{W}^{6+}$, - образуются молибдошеелиты. Шеелит обычно образует кристаллы тетрагонального дипирамидального габитуса, вкрапленность идиоморфных зерен или сросшиеся зернистые агрегаты. Размер кристаллов разный. Цвет минерала бывает белый, бело-желтый, бежевый (у шеелита), реже оранжевый, серовато-белый (у молибдошеелита), иногда и черный (с вростками молибденита).

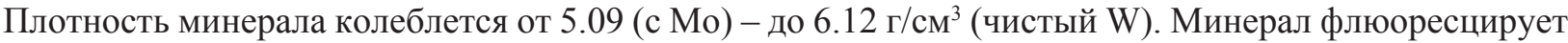
в ультрафиолете, имеет синее свечение. Шеелиты разных месторождений могут содержать разные примеси в своем составе: в частности, отмечается различие шеелитов медно-молибден-порфировых и золоторудных месторождений. Именно подобные объекты и состав шеелитов в них мы рассмотрим для архейских месторождений Карелии. В Карелии известно 11 небольших проявлений вольфрама, представленных в скарнах и грейзенах С. Приладожья (PR), и лишь несколько объектов из- 
вестны в штокверках медно-молибден-порфировых месторождений и проявлений (AR), связанных с гранитоидами в архейских зеленокаменных поясах (Минерально..., 2005).

Целью работы является изучение особенностей составов шеелитов архейских комплексных $\mathrm{Au}-\mathrm{Cu}-\mathrm{Mo-порфировых} \mathrm{рудных} \mathrm{объектов} \mathrm{Карелии.}$

\section{Фактический материал и методы исследования}

В работе изучался шеелит комплексных медно-молибден-порфировых и золоторудных объектов (месторождений и проявлений) Карелии - Лобаш, Лобаш-1, Ялонвара. Образцы для исследований были отобраны из руд разного типа, измененных пород и жил. Состав рудных минералов определялся с помощью электронного сканирующего микроскопа VEGA II LSH (Tescan) с энергодисперсионным микроанализатором INCA Energy-350 (Oxford instruments). Состав зональных шеелитов анализировался, по возможности, вкрест существующей зональности. Параметры съемки: $\mathrm{W}$-катод, напряжение 20 кB, время сканирования в стандартных режимах съемки 90 сек. Микрокомпонентный состав руд и геохимические особенности вмещающих пород определялись с использованием ICP-MS-анализа в аналитическом центре ИГ КарНЦ РАН (г. Петрозаводск) по существующей методике прибора.

\section{Результаты исследований: геохимия и минералогия руд, состав шеелитов}

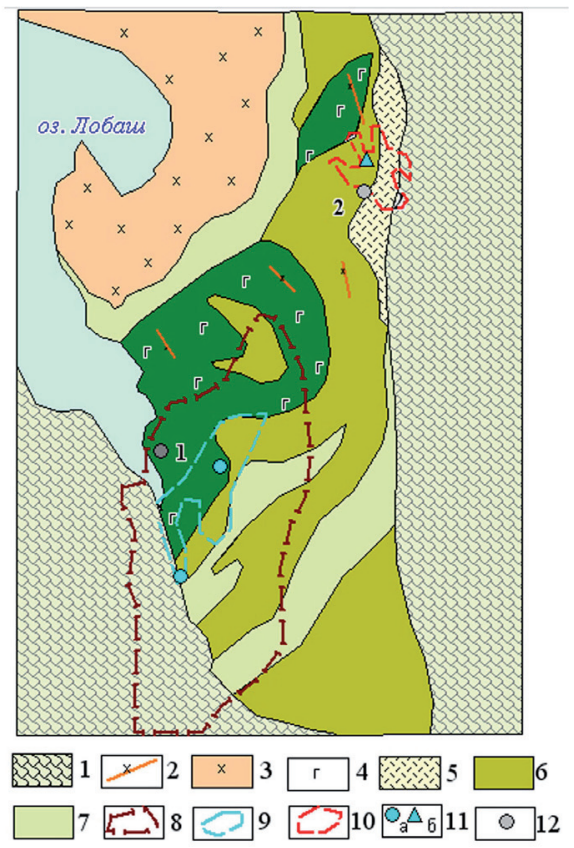

Рис. 1. Схема геологического строения рудного поля Лобаш:

1 - вулканогенно-осадочные отложения PR1sm; 2 - дайки гранит-порфиров, 3 - гранодиориты 1 фазы, 4 - габбро, 5-7 - вмещающие AR-толщи: 5 - риодациты, 6 - андезиты и их туфы, 7 - базальты; 8 - контур гранитного тела (гранит-порфиры 2 фазы). Рудные тела: 9 - Mo, 10 - Au-(Pb-Zn-Cu), 11 - отдельные скважины, 12 - места отбора образцов с шеелитом.

Fig. 1. Scheme showing the geological structure of the Lobash Ore Field.
Геологическое строение месторождений и проявлений рудных полей Лобаш и Ялонвара отражено в производственных геологических отчетах и приводится в ряде публикаций (Минерально..., 2005; Иващенко, Лавров, 1994; 1998; Кулешевич и др., 2004 а, б; Тытык, Фролов, 2014) и продемонстрировано на рисунках 1-2. Медно-молибденпорфировые и ассоциирующие с ними золото-сульфидные месторождения/проявления формируются в ореолах многофазных гранодиорит-гранит-порфировых массивов.

На молибденовом месторождении Лобаш (Беломорский район, северная Карелия; рис. 1) зональный молибдошеелит встречается в ассоциации с пиритом, молибденитом, халькопиритом, в краевой части рудного молибденитового штокверка в измененных породах основного состава. Шеелит обычно находится в срастании с пиритом, образует гнезда - скопления в маломощных прожилках. Пирит кристаллизуется первым, затем выделяется шеелит. Молибденит образуется позднее, он сечет и по трещинкам проникает в пирит, окружает шеелит. В ассоциации с ними иногда встречаются галенит и висмуто-теллуриды. Шеелит образует зональные с кристаллы (рис. 3): в центральной части они бывают представлены молибдошеелитом, с краев - однородным шеелитом. Зональность обычно контрастная, резкая. В крупных зернах - колеблющаяся с тонкими полосамизонами (осцилляторная). Мелкие зерна шеелита чаще бывают однородны. Кроме того, в измененных габброидах шеелит встречается в мельчайших $(<1-2 \mu \mathrm{m})$ округлых включениях в титаните. Шеелит содержит примесь Мо до 0.01-0.3 \%, молибдошеелит - от 5.0 - до $27.53 \%$ Мо (табл. 1). Содержание $\operatorname{Re}$ в молибдошеелитах достигает $3.5 \%$. Значительных скоплений W-минералов, подобных проявлению Ялонварское, не установлено. 
Таблица 1. Состав шеелитов-молибдошеелитов (мас. \%).

Table 1. Composition of scheelite-molybdoscheelite (mas. \%).

\begin{tabular}{|l|c|c|c|c|c|c|c|c|c|c|c|c|}
\hline Компонент & 1 & 2 & 3 & 4 & 5 & 6 & 7 & 8 & 9 & 10 & 11 & 12 \\
\hline $\mathrm{CaO}$ & 18.25 & 18.91 & 19.29 & 18.94 & 20.73 & 18.81 & 17.74 & 18.61 & 18.44 & 17.99 & 19.39 & 18.39 \\
\hline $\mathrm{WO}_{3}$ & 81.75 & 69.99 & 69.73 & 60.97 & 51.74 & 82.13 & 82.26 & 71.28 & 81.52 & 76.41 & 67.37 & 67.41 \\
\hline $\mathrm{MoO}_{3}$ & & 5.86 & 10.97 & 20.08 & 27.53 & & & 10.11 & & 5.60 & 13.24 & 10.70 \\
\hline № обр. & Л-1 & 1 & 1 & 1 & 1 & Л-2 & Я-1 & 1 & Я-2 & 2 & 2 & 2 \\
\hline$\sum$ & 100 & 100 & 99.99 & 99.99 & 100 & & 100 & 100 & 99.96 & 100 & 100 & 96.50 \\
\hline
\end{tabular}

Примечание. 1-5 - Лобаш, 6 - Лобаш -1, 2 - 3.5 \% $\operatorname{Re}_{2} \mathrm{O}_{7}$. 7-12 - Ялонварское (Хатуноя), $12-3.5 \% \operatorname{Re}_{2} \mathrm{O}_{7}$.

Золото-полиметаллическая минерализация месторождения Лобаи-1 приурочена к прожилкам и развивается в измененных породах преимущественно среднего состава типа пропилитов, представленных срастанием эпидота, кварца, кальцита, хлорита. В золотосодержащих сфалеритхалькопирит-пирротиновых рудах месторождения шеелиты более однородные по составу образуют редкие вкрапления размером до 0.5 мм. Шеелит образует овальные зерна и хорошо ограненные кристаллы (рис. 1), иногда, как и в первом типе руд, встречается в форме мельчайших включений в титаните. Выделяется шеелит обычно первым, встречается включенным в пирротин, халькопирит и в срастании с ними в силикатах. В шеелитах месторождения Лобаш-1 - Мо не установлен (табл. 1).
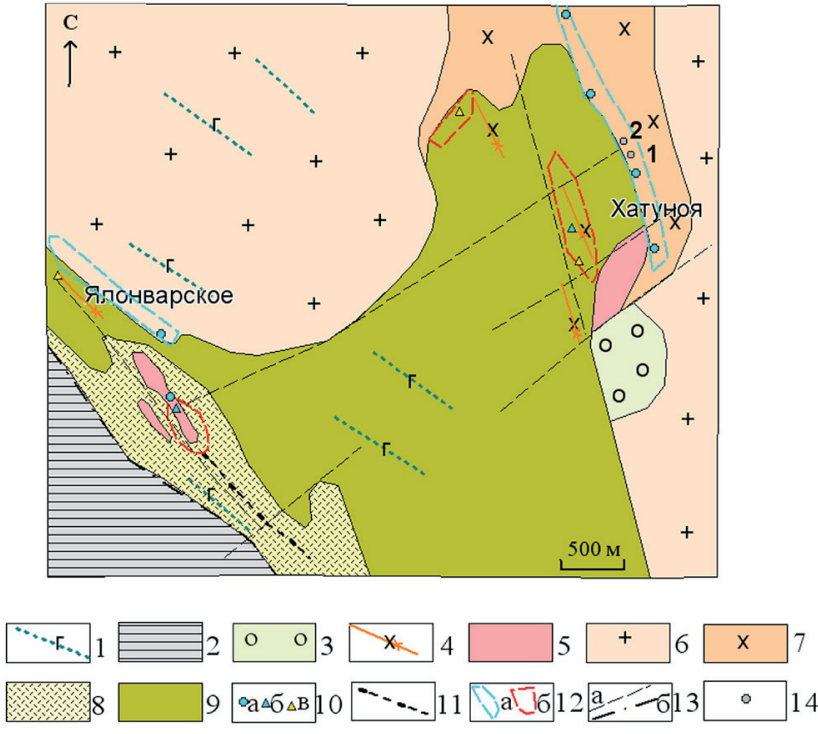

Рис. 2. Схема геологического строения рудного поля Ялонвара:

1 - дайки габбродолеритов PR1; 2 - PR1- комплекс пород; 3 - конгломераты (PR1sr); 4-7 - Ялонварский гранитный комплекс: 4 - дайки и 5 - малые тела гранит-порфиров, лейкогранитов, 6 - граниты, 7 - диориты; 8-9 - AR-вулканогенно-осадочные толщи: 8 - кислого состава, 9 - андезиты и их туфы; 10 - рудная минерализация: а - Мо, б - полиметаллические ( $\mathrm{Pb}-\mathrm{Zn}-\mathrm{Cu})$, в - $\mathrm{Cu} ; 11$ - колчеданы, 12 - ореолы: a - Mo, $\sigma$ - (Pb-Zn-Cu), 13 - тектонические зоны: а сдвиговые, б - зона AR-PR, 14 - образцы с шеелитом.

Fig. 2. Scheme showing the geological structure of the Jalonvaara Ore Field.

В рудном поле Ялонвара на рудопроявлениях Ялонварском и Хатуноя (юго-западная Карелия; рис. 2) обильная шеелит-(молибдошеелит)-молибденитовая минерализация приурочена к кварцевым прожилкам в измененных диоритах. Прожилки мощностью до 10 см имеют преимущественное С3 и СВ простирание, в целом формируя штокверк на площади 500-700 м² (к югу от оз. Ялонваранъярви). В них в ассоциации с пиритом и шеелитом установлены сульфиды $\mathrm{Cu}, \mathrm{Zn}$, минералы висмута, апатит, титанит и турмалин. Аналогичная редкометалльная ассоциация сосредоточена также и в эпидот-биотитовых метасоматитах (биотититах), образующих метасоматические оторочки около кварцевых жил среди диоритов. Минералы $\mathrm{W}$ и Мо встречаются во вкрапленности и гнездах размером до 0.5-0.7 см в поперечнике. В таких рудах устанавливается неоднородное, «пятнистое» строение W-Мо гнезд и скоплений - темные и светлые участки (рис. 4). На фоне более светлых участков, по составу отвечающих шеелиту, наблюдаются более темные зоны, представленные молибдошеелитами, которые содержат от 7.79 до 11.6 мас. \% Мо. Кроме того в «темных» молибдошеелитах установлены кристаллографически ориентированные пластинчатые микровключения молибденита-1, тогда как в «светлых» шеелитах, выделяются более крупные скопления лейст молибденита-2 (рис. 4/в-г, ж). 


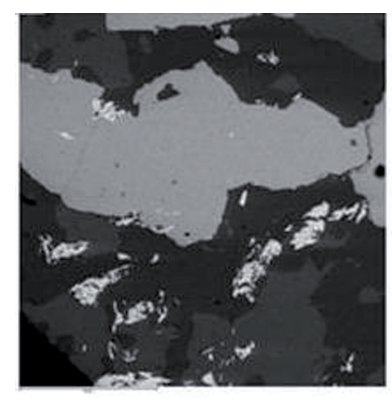

a

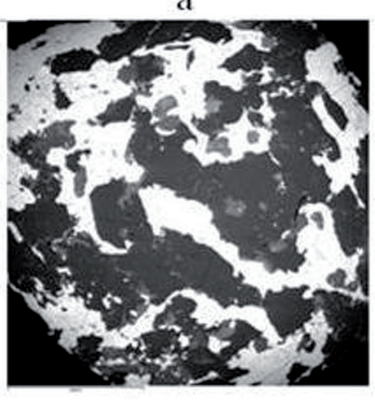

Д

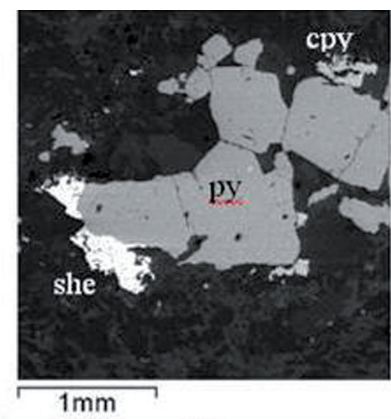

6

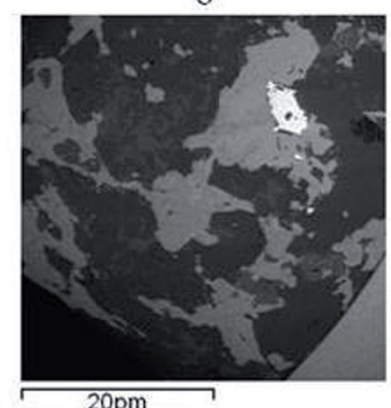

e

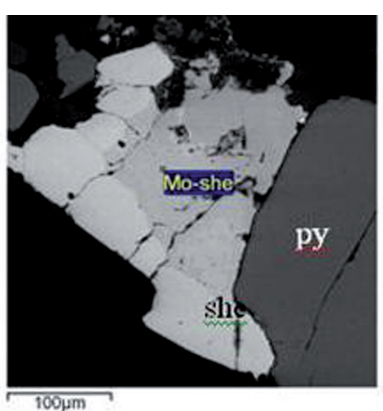

B

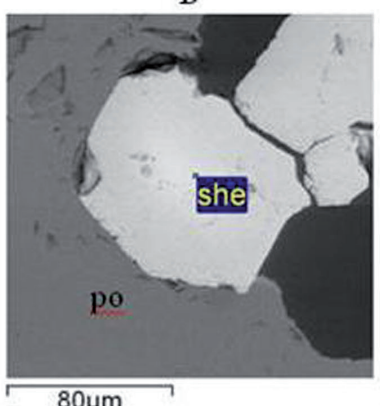

ж

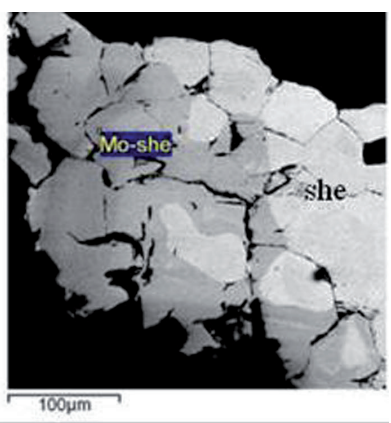

$\Gamma$

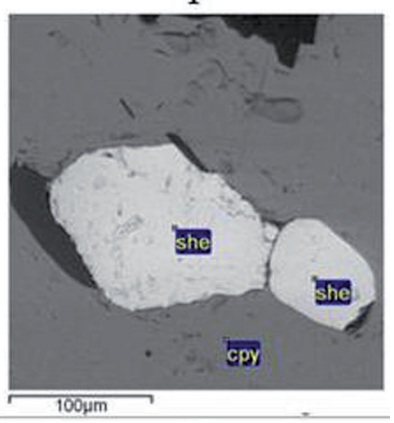

3

Рис. 3. Шеелиты-молибдошеелиты в рудах месторождений Лобаш (а-г), Лобаш-1 (д-е):

a - соотношение пирита и молибденита в рудах, б - пирит, шеелит, халькопирит, в - зональный шеелитмолибдошеелит в срастании с пиритом, г - молибдошеелит зональный; д-золото-содержащие полиметаллические (галенит-сфалерит-халькопирит-пирротиновые) руды, е - шеелит в срастании с пирротином и халькопиритом, ж-з - шеелит в срастании с халькопиритом.

Fig. 3. Scheelite-molybdoscheelite in ores from Lobash (a-d) and Lobash-1 (e-f) deposits:

$\mathrm{a}$ - pyrite-molybdenite ratio in ores, $\mathrm{b}$ - pyrite, scheelite, chalcopyrite, $\mathrm{c}$-zonal scheelite-molybdoscheelite intergrown with pyrite, $\mathrm{d}$ - zonal molybdoscheelite; e - auriferous base-metal (galena-sphalerite-chalcopyrite-pyrrhotite) ores, $\mathrm{f}$ - scheelite intergrown with pyrrhotite and chalcopyrite, g-h - scheelite intergrown with chalcopyrite.

Молибдошеелит обрастает шеелитом, одновременно с этим выделяется основная масса молибденита. Иногда в шеелитах встречаются гораздо более светлые пятнистые включения Re-содержащего шеелита (до 3-4 мас. \% Re в составе шеелита) (рис. 4 з).

Кроме того, в кварц-пиритовых золото-содержащих прожилках среди вышеупомянутых диоритов, а также в сдвиговых зонах с окварцеванием и обильной пиритовой минерализацией в экзоконтакте гранитоидов установлены отдельные однородные зерна шеелита.

Геохимия руд. Содержание $\mathrm{W}$ в рудах молибденитового штокверка месторождения Лобаш (по изученным образцам) составляет 18-180 г/т, в шеелит-молибденит пиритовых - 435 г/т, в золотосодержащих полиметаллических от 1-3 г/т - иногда до 89 г/т. В богатых молибденитовых рудах Ялонвары установлено 2-33 г/т W, в шеелит-молибденитовых - 133-1398 г/т, в золотосодержащих медно-полиметаллических 1-46 г/т (данные ICP-MS-анализа). Максимальные содержания $\mathrm{WO}_{3}$ в рудах достигают $1 \%$. Для рудопроявления Ялонварское рассчитаны ресурсы вольфрама категории Р3 - 4 тыс. т (Минерально..., 2005).

\section{Заключение}

Вольфрамовая минерализация архейских золото-содержащих $\mathrm{Cu}-\mathrm{Mo-порфировых} \mathrm{месторож-}$ дений/рудопроявлений рудных полей Лобаш и Ялонвара представлена шеелитами и молибдошеелитами.

На месторождении Лобаш существующая в шеелите зональность, указывает на кристаллизацию с пульсационной сменой концентрации растворов: в шеелитах наблюдается зональность от чистых вольфрамовых - к Мо-содержащим и последующее отложение молибденита во вкрапленности 


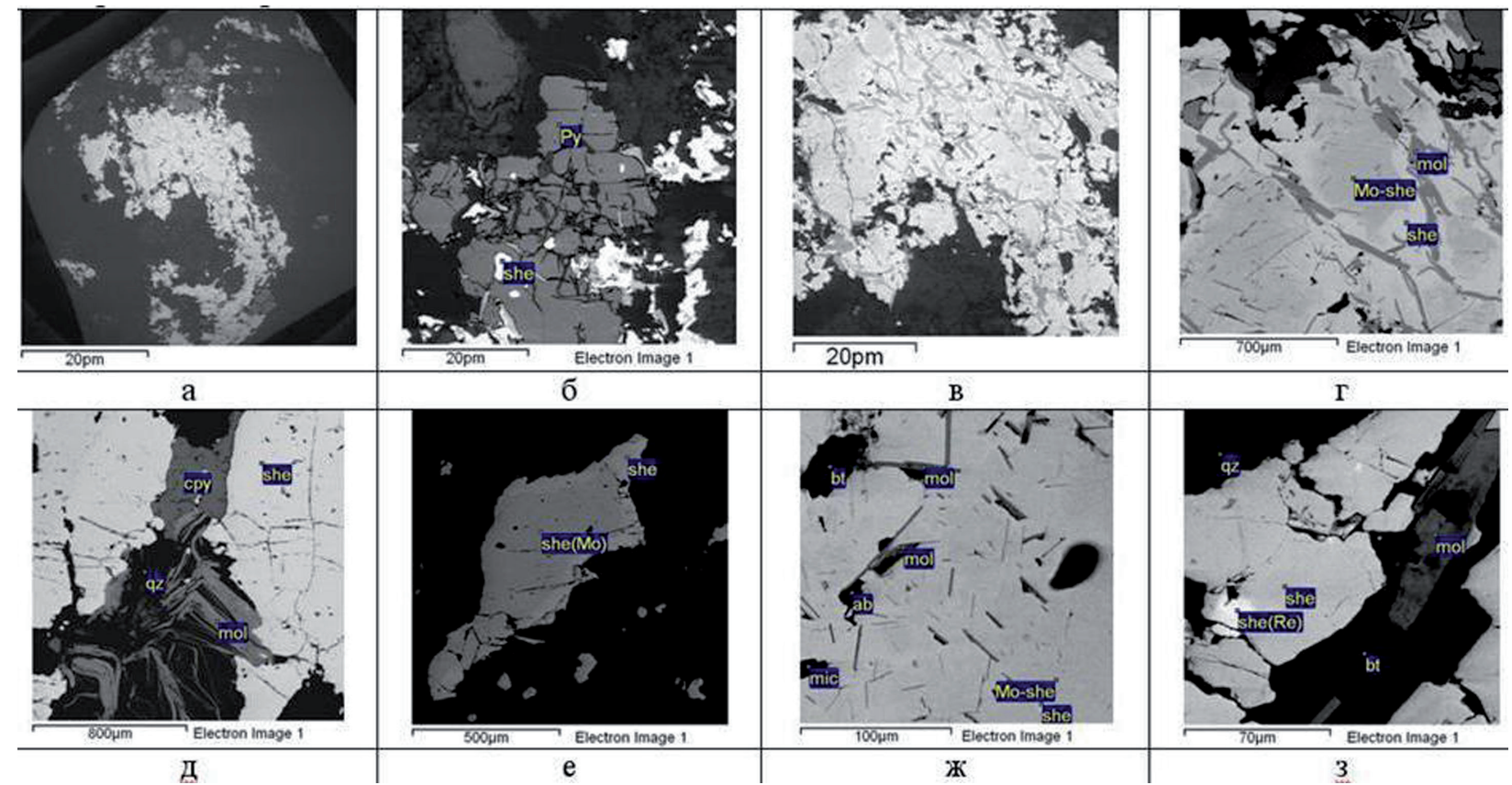

Рис. 4. Шеелиты в Cu-W-Mo-рудах проявления Ялонвара:

a - прожилково-гнездовые пирит-молибденит-шеелитовые руды, б - срастание пирита и шеелита, в -шеелитмолибдошеелитовые гнезда с вростками молибденита, г - соотношение молибдошеелита, шеелита и молибденита-1 и 2, д- срастание халькопирита, молибденита-2 и шеелита, е - зональный шеелит, ж - тонкие пластинки молибденита-1 в молибдошеелите, з - включения Re-содержащего шеелита в шеелите.

Fig. 4. Scheelites in $\mathrm{Cu}-\mathrm{W}-\mathrm{Mo}$-ores from the Jalonvaara occurrence:

a - streaky-pocket pyrite-molybdenite-scheelite ores, $\mathrm{b}$ - pyrite-scheelite intergrowth, $\mathrm{c}$-scheelite-molybdoscheelite pockets with molybdenite ingrowths, $\mathrm{d}$ - molybdosheelite-scheelite-molybdenite-1 and 2 ratio, e - chalcopyrite molybdenite-2 - scheelite intergrowth, f - zonal scheelite, $\mathrm{g}$ - thin molybdenite-1 lamellae in molybdoscheelite, $\mathrm{h}$ - Re-bearing inclusions in scheelite.

и жилах. В рудах золото-полиметаллического месторождения Лобаш-1 вкрапленные шеелиты более однородны по составу. W-минерализация более редкая, чем в Ялонваре.

На проявлениях рудного поля Ялонвара наблюдается смена состава шеелитов: от молибдошеелитов с избыточными концентрациями Мо, сопровождающимися выпадением тонких ламеллей молибденита-1, до чистых шеелитов в срастании с мелкочешуйчатым молибденитом-2. Руды проявлений рудного поля Ялонвара более обогащены вольфрамом. Формирование (W)-Мо и благороднометалльной минерализации в них совмещено и сближено по времени. Шеелиты золото-пириткварцевого типа руд однородны.

Содержание Мо в молибдошеелитах колеблется и составляет 5-27.5 \%. Рений как примесь установлен в молибдените обоих типов рудных объектов (Богачев и др., 1999), также он обнаружен в молибдошеелитах. Однако вопрос о вхождении Re в состав молибдошеелитов требует дополнительного изучения.

Работа выполняется в рамках темы НИР № ГР АААА-А18-118020290084-7.

\section{Литература}

1. Богачев В.А. и др. 1999. Осмий и рений в молибденитах гранит-порфировых проявлений Карелии // Минерал. геол. журнал. 1999. № 1. С. 13-15.

2. Иващенко В.И., Лавров О.Б. Магматогенно-рудная система Ялонварского вулкано-плутонического комплекса архея Карелии. Петрозаводск. Изд-во: КарНЦ РАН. 1994. 127 с.

3. Иващенко В.И., Лавров О.Б. Комплексное порфировое месторождение Ялонвара в архее Карелии (Россия) // Геология рудных месторождений. 1996. Т. 38. № 5. С. 412-423. 
4. Кулешевич Л.В., Тытык В.М., Коротаева Н.Н. Минералогия руд и околорудно-измененных пород золото-полиметаллического месторождения Лобаш-1 (Карелия) // Записки РМО. 2004. № 4. С. 39-51.

5. Кулешевич Л.В., Тытык В.М., Коротаева Н.Н. Золото-полиметаллическое месторождение Лобаш-1 в докембрии Карелии // Геология и полезные ископаемые. 2004. С. 111-126.

6. Минерально-сырьевая база Р. Карелия. Петрозаводск. Изд-во: Карелия. 2005. 278 с.

7. Тытык В.М., Фролов П.В. Молибденовое месторождение Лобаш - крупный перспективный объект в Республике Карелия // Труды КарНЦ РАН. 2014. № 1. С. 56-62. 